\author{
AnNa Fiń \\ Uniwersytet Pedagogiczny w Krakowie \\ Agata Nijander-Dudzińska \\ Akademia Ignatianum w Krakowie
}

\title{
PRZEMYŚL I SANOK - SPOŁECZNO-KULTUROWA CHARAKTERYSTYKA SPOŁECZNOŚCI LOKALNYCH
}

\section{Uwagi wstępne}

Prezentowany artykuł ma na celu ukazanie społeczno-kulturowego charakteru dwóch miejscowości: Przemyśla i Sanoka. Głównym kontekstem dla podjęcia tego przedsięwzięcia są badania przeprowadzone w ramach projektu Odświętne tworzenie i propagowanie marek (narodowej, lokalnej, regionalnej) w społecznościach lokalnych, którego celem była diagnoza oddolnego i odświętnego mechanizmu tworzenia marki lokalnej i narodowej. Proces tworzenia marki lokalnej, regionalnej czy narodowej jest nierozerwalnie związany ze specyfiką społeczną oraz kulturową określonej społeczności czy regionu.

Dlatego wśród zmiennych różnicujących uwzględnione $\mathrm{w}$ badaniu miejscowości i organizowane w nich wydarzenia kulturalne znalazło się położenie geograficzne oraz dziedzictwo kulturowe i historyczne miast. Wybór Przemyśla i Sanoka nie był w tej sytuacji przypadkowy. Obydwa miasta położone są w południowo-wschodniej Polsce, na obszarze pogranicza polsko-ukraińskiego. Już samo przygraniczne położenie badanych miejscowości decyduje o ich zróżnicowanym pod względem kulturowym charakterze, co związane jest $\mathrm{z}$ obecnością mniejszości ukraińskiej jak również z przepływami ukraińskich imigrantów. Źródła kulturowego zróżnicowania tego obszaru tkwią także w przeszłości i wiążą się z współwystępowaniem na tym terenie elementów kultur: polskiej, ukraińskiej, żydowskiej, niemieckiej, co oznacza, że procesy owego zróżnicowania tak jak „procesy pluralizacji mają wiele wymiarów, części składowych, poziomów przejawiania się i kierunków" [Babiński 2004: 211]. Mają też one charakter dynamiczny, ulegają zmianom w historii i wpływają na podejmowane 
obecnie działania. Stąd też, w naszym przekonaniu, uwzględnienie społeczno-kulturowego opisu badanych miejscowości umożliwi bardziej adekwatne i trafne wnioskowanie o elementach używanych do tworzenia lokalnych marek.

Zaprezentowana społeczno-kulturowa charakterystyka badanych miejscowości uwzględnia takie konteksty funkcjonowania Przemyśla i Sanoka jak: historia i współczesne uwarunkowania strukturalne miast; aktywność kulturalną i opis lokalnych zasobów kultury oraz charakterystykę świąt/ wydarzeń kulturalnych, które zostały wytypowane do analiz szczegółowych (w przypadku Przemyśla - Wincentiadę; a w przypadku Sanoka Jarmark Sanocki).

\section{Społeczno-kulturowa charakterystyka miasta Przemyśl}

\section{Historia i współczesność}

Przemyśl jest miastem wyjątkowym, o ponad tysiąc letniej historii, niegdyś ważnym ośrodkiem Galicji, niezwykle malowniczym i urokliwym, położonym niczym Rzym na siedmiu wzgórzach, przeciętym wstęgą Sanu. (...) Przemyśl to pogranicze kultur, narodowości i religii, miejsce niezwykłe, pełne magii i niespodzianek, nazywane Verdun Wschodniego Frontu, Bramą i Tyglem Kulturowym, Bramą Zjednoczonej Europy, Stolicą Dzwonków i Fajek, Perłą Karpackiej Przyrody [Strategia rozwoju turystyki..., 2007: 59].

Te zapisane w jednej ze strategii rozwoju miasta zdania poniekąd wprowadzają w specyfikę badanej miejscowości. Bardziej szczegółowe opisanie charakteru miasta czy też jego społeczno-kulturowego profilu wymaga jednak uwzględnienia szeregu dodatkowych czynników, przy czym zasadnicze znaczenie mają następujące zmienne: położenie geograficzne, uwarunkowania historyczne, czynniki demograficzne, jak również polityczne i ekonomiczne.

Miasto Przemyśl położone jest na obszarze południowo-wschodniej Polski, w województwie podkarpackim. Usytuowane jest w bezpośrednim sąsiedztwie granicy z Ukrainą (Medyka, Korczowa) oraz Słowacją (Barwinek). Znajduje się ono w dolnie rzeki San, u zbiegu trzech krain geograficznych: Niziny Sandomierskiej, Pogórza Karpackiego i Przedgórza Karpat Wschodnich. Takie położenie geograficzne, z jednej strony wpływa na peryferyjność miasta, $z$ drugiej jednak strony na jego atrakcyjność turystyczną oraz ciekawy układ przestrzenny. O specyfice Przemyśla w znacznej mierze decydują jednak uwarunkowania historyczne. Miasto nie tylko 
należy do jednych z najstarszych w Polsce, ale przez całe swoje istnienie pozostawało pod wpływem oddziaływań rożnych centrów politycznych i kulturowych. W wieku XI i XII o wpływy polityczne na ziemi przemyskiej walczyli Polacy, Rusini, Węgrzy oraz Tatarzy. Generalnie, obszar ten na przestrzeni wieków pozostawał w ramach różnych organizmów państwowych: do 1340 roku Księstwa Halickiego, do 1772 Polski, do 1918 roku Austrii, a potem znów Polski. Czynniki geopolityczne oraz historyczne miały bezpośredni wpływ na ukształtowanie się w Przemyślu zróżnicowanej pod względem kulturowym i etnicznym społeczności miejskiej, którą oprócz Polaków tworzyli: Ukraińcy, Żydzi oraz Niemcy. Czasem największego rozkwitu Przemyśla, po którym pozostały unikalne zabytki architektury i sztuki był okres jagielloński (wiek XIV-XVII) oraz druga połowa wieku XIX. W okres II Rzeczypospolitej Polskiej Przemyśl wszedł jako trzecie co do wielkości miasto (po Lwowie i Krakowie) zaboru austriackiego oraz prężny ośrodek kulturowy ${ }^{1}$. Sytuację zmieniły lata II wojny światowej ${ }^{2}$ oraz okres komunizmu w Polsce, które doprowadziły do całkowitej zmiany składu społecznego miasta: zaniku społeczności żydowskiej oraz likwidacji zorganizowanych form życia społeczno-kulturowego mniejszości ukraińskiej (odrodziło się ono dopiero po transformacji ustrojowej w 1989 roku). Badacze problematyki zwracają uwagę, że w rezultacie tych procesów Przemyśl z miasta pluralistycznego, stał się "praktycznie monolityczny wyznaniowo, a także narodowo i etnicznie" [Borowik, Dyszewska, Litak 2008: 103]. Dziś miasto opisywać zatem należy bardziej w kategoriach dziedzictwa zróżnicowania etnicznego i kulturowego niż rzeczywistego pluralizmu. Choć obecnie struktura etniczna Przemyśla nie jest taka złożona jak to miało miejsce w przeszłości; $w$ dalszym ciągu w jego krajobraz kulturowy wpisują się różne wyznania i grupy etniczne. Po pierwsze wspomnieć należy, że miasto jest faktyczną stolicą arcybiskupów dwóch obrządków katolickich (rzymskiego i greckiego) i formalną stolicą biskupstwa prawosławnego ${ }^{3}$; po drugie

1 Przez badaczy dziejów Przemyśla w tzw. okresie galicyjskim miasto opisywane jest w kategoriach „miasta sukcesu”, [zob. Sobala-Gwosdz 2008: 187].

2 W mieście oraz jego okolicach doszło do znaczących przemian demograficznych, które były rezultatem głównie przymusowych ruchów migracyjnych (deportacji, wysiedleń) oraz strat osobowych ludności [zob. więcej: Dalecki 2000-2002: 87-101].

3 Obecnie struktura wyznaniowa przedstawia się następująco: poza Kościołem rzymskokatolickim; kościół greckokatolicki (ok. 2000 wyznawców), Ŝwiadkowie Jehowy (250-300 osób); Kościół zielonoświątkowy (ok. 215); Kościół metodystyczny (ok. 115); Kościół prawosławny (ok. 80); Kościół adwentystyczny (26); Kościół baptystyczny (15). Co więcej, jak wynika z dotychczas prowadzonych badań cechą charakterystyczną Przemyśla jest „niekwestionowany związek między tożsamością religijną a tożsamością narodową i etniczną jego mieszkańców" [więcej na temat: Borowik, Dyszewska, Litak 2008:103-104]. 
ok. 3\% mieszkańców stanowi ludność ukraińska, która posiada tu ważne dla siebie i prężnie działające instytucje świeckie; po trzecie wreszcie stosunkowo widoczna w przestrzeni miasta jest również społeczność romska oraz azjatycka (przybywający od połowy lat dziewięćdziesiątych imigranci). Obecnie Przemyśl jest partnerskim miastem takich europejskich miast jak: Paderborn (Niemcy), Lwów (Ukraina), Kamieniec Podolski (Ukraina), Eger (Węgry), Truskawiec (Ukraina).

Na społeczno-kulturowy obraz miasta wpływa również fakt, że w latach 1975-1999 pełniło ono rolę stolicy istniejącego wówczas województwa przemyskiego. Zmiany administracyjne w podziale państwa, jakie dokonały się w roku 1999 sprawiły, że obecny Przemyśl jest gminą miejską wykonującą zadania miasta na prawach powiatu. Przestrzeń polityczną współczesnego Przemyśla charakteryzuje z jednej strony dostosowywanie się do ogólnie panujących trendów w polityce; $z$ drugiej strony swego rodzaju tendencja do odtwarzania sytuacji czy układu politycznego i przywiązanie do partii o charakterze konserwatywnym (narodowy konserwatyzm (PiS) i konserwatywny liberalizm $\left.(\mathrm{PO})^{4}\right)$ : czwartą kadencję prezydentem miasta jest Robert Choma - najpierw kandydat lokalnego komitetu prawicy oraz Prawa i Sprawiedliwości; potem, od 2010 roku, kandydat bezpartyjny, przedstawiciel własnego komitetu wyborczego Regia Civitas. Oprócz dwóch dominujących partii politycznych PiS i PO ważnymi aktorami przemyskiej sceny politycznej są także takie partie, jak PSL oraz SLD Lewica Razem, dla których poparcie w ostatnich wyborach samorządowych (2014 rok) oscylowało w granicach 10\% [Państwowa Komisja Wyborcza]. Partie reprezentujące opcje eurosceptyczne (Nowa Prawica; Ruch Narodowy) oraz opowiadające się za ideologią narodowego katolicyzmu (np. Ruch Narodowy) nie cieszą się szerokim poparciem wśród mieszkańców miasta (Nowa Prawica, 5,3\% poparcia, Ruch Narodowy - 4,7\%), [Borowik, Dyszewska, Litak 2008]. Co więcej, analiza zmian poparcia dla poszczególnych aktorów przemyskiej sceny politycznej w latach 2006-2014 wskazuje na utrzymywanie się swego rodzaju wzorca poparcia dla ugrupowań lewicowo-liberalnych; pozycji PO (w 2010 roku - 27,5\% poparcia) i wahającego się poziomu popularności PiS (w roku 2006 - 41\%, zaś w roku 2010 spadek do 19,9\% poparcia). Dane te $\mathrm{w}$ zasadzie świadczą o wskazanej już tendencji przemyskiej przestrzeni

\footnotetext{
Prawo i Sprawiedliwość oraz Platforma Obywatelska RP to wiodący aktorzy przemyskiej sceny politycznej. Wyniki wyborów samorządowych wskazują na w zasadzie równorzędną siłę tych ugrupowań: poparcie dla PiS wyniosło 34,75\%, a dla PO - 29,74\%. Zob:. Państwowa Komisja Wyborcza: Wybory i Referenda http://pkw.gov.pl/352_Wybory_i_referenda, [20.04.2017].
} 
politycznej do odtwarzania przeszłych układów politycznych i przywiązania mieszkańców do określonych partii politycznych.

Analiza różnych współczesnych uwarunkowań strukturalnych funkcjonowania miasta $\mathrm{w}$ pierwszej kolejności wskazuje na niezbyt dynamiczny rozwój demograficzny Przemyśla. Według danych GUS w roku 2014 miasto liczyło 63441 tysięcy mieszkańców, a gęstość zaludnienia wynosiła 1374 osoby $/ \mathrm{km}^{2}$. W strukturze ludności przeważają kobiety (współczynnik feminizacji wynosi 113), znaczny jest też udział osób w wieku poprodukcyjnym $(21,3 \%)$ i stosunkowo niski jest wskaźnik udziału w populacji ludzi młodych (ich odsetek wynosi jedynie 16,6\%), [Bank Danych Lokalnych]. Oprócz procesu starzenia się populacji miasto charakteryzuje utrzymujący się od roku 2006 spadek liczby ludności ${ }^{5}$, który generowany jest przez ujemny przyrost naturalny oraz ujemne saldo migracji wewnętrznych i zagranicznych ${ }^{6}$. W literaturze przedmiotu zwraca się także uwagę na niedostateczny rozwój gospodarczy miasta, który spowodowany jest peryferyjnym położeniem Przemyśla oraz niskim „uprzemysłowieniem”7 Wiodącymi działami gospodarki są tutaj handel i usługi, determinowane zresztą przygranicznym położeniem miasta. Generalnie sytuacja ekonomiczna nie jest pozytywna, a stopa bezrobocia od wielu już lat utrzymuje się powyżej średniej wojewódzkiej oraz ogólnopolskiej (na koniec roku 2014 wynosiła ona $17 \%)$. Ponadto za główne, zdiagnozowane problemy miasta uznaje się: niski status materialny części mieszkańców Przemyśla oraz niewystarczający poziom inwestycji gospodarczych realizowanych w mieście [Strategia sukcesu miasta Przemyśla na lata 2014-2024, 2014]. Jednocześnie należy zauważyć, że Przemyśl jest miastem dwóch przedsiębiorstw notowanych w Rankingu polskich marek „Rzeczpospolitej”. Producent kosmetyków Inglot i producent obuwia Kazar w X edycji rankingu, w roku przeprowadzonych badań (2013) znajdowały się odpowiednio na 151 i 220 pozycji [Ranking 2013: 14-15]. Inglot w swojej branży był trzecią notowaną marką [Ranking 2013: 29]. Po trzech latach potencjał obu marek wzrósł, co

5 Od 2006 do 2013 liczba ludności w mieście spadła o ponad 5\%, zob. więcej: Analiza sytuacji na przemyskim rynku pracy 2014-2015, http://www.pup.przemysl.pl/FCK/file/pliki\%20do\%20pobrania/ Analiza_sytuacji_na_przemyskim_rynku_pracy_lata_2014_2015.pdf, [20.03.2015].

6 Saldo migracji wewnętrznych wynosi 182; saldo migracji zagranicznych - 26; [Bank Danych Lokalnych].

7 Zdaniem badaczy problematyki nie jest to zjawisko korzystne, gdyż nie generuje na odpowiednim poziomie transferu zarówno technologii, jak i wykwalifikowanej kadry, spowalniając tym samym rozwój gospodarczy, zob. więcej: [Analiza sytuacji na przemyskim rynku pracy: 4; [Sobala-Gwosdz 2008: 190-192]. 
oznaczało, że Inglot w 2016 roku był notowany na 127 pozycji, a Kazar na 183 wspomnianego rankingu [Ranking 2017: 15, 17].

Już ten skrótowy opis uwarunkowań historycznych i współczesnych, strukturalnych ram funkcjonowania miasta pozwala opisywać je jako społeczność, będącą na przestrzeni lat w procesie przemian: administracyjnych, gospodarczych, politycznych i kulturowych. Z jednej strony ich skutkiem jest obecna niekorzystna sytuacja gospodarcza miasta, $\mathrm{z}$ drugiej jednak strony to właśnie te uwarunkowania stanowią kapitał społeczno-kulturowy Przemyśla. W takich kategoriach rozpatrywać można bowiem wspomniane dziedzictwo zróżnicowania kulturowego i współczesne przejawy pluralizmu wyznaniowego. Elementem owego kapitału są także lokalne zasoby kultury.

\section{Lokalne zasoby kultury}

Charakterystyka lokalnych zasobów kultury przedstawia się zupełnie odmiennie niż sytuacji społeczno-gospodarczej miasta. Przede wszystkim Przemyśl przedstawia się jako miasto o dużym potencjale kulturowym, który generowany jest przez takie czynniki, jak: a) wyjątkowe w skali kraju nasycenie obiektami zabytkowymi, b) układ architektoniczno-urbanistyczny $\mathrm{z}$ wieloma obiektami sakralnymi, c) zachowane systemy obronne od X do XX wieku; d) bardzo bogaty zasób zabytków ruchomych (rzeźba rokokowa kręgu lwowskiego, ikony, fajki, dzwony), e) kompleks zabytkowych wielonarodowościowych cmentarzy, f) oferta akademicka ${ }^{8}$ i kształcenia ustawicznego; a także g) funkcjonowanie wielu instytucji kultury i bogaty kalendarz imprez kulturalnych. W kontekście prowadzonych badań szczególnego znaczenia nabiera omówienie tych ostatnich czynników. W kulturalny obraz miasta wpisują się instytucje, jednostki i placówki kultury (utrzymywane ze środków: Urzędu Marszałkowskiego Województwa Podkarpackiego, Urzędu Miejskiego w Przemyślu, Ministerstwa Kultury i Dziedzictwa Kulturowego, Kurii Metropolitarnej oraz Przemyskiej Spółdzielni Mieszkaniowej); stowarzyszenia społeczno-kulturalne oraz współpracujący z nimi lokalni artyści. Generalnie według szacunków GUS w 2012 roku

8 Akademicką bazę miasta tworzą: Państwowa Wyższa Szkoła Wschodnioeuropejska w Przemyślu (dawna PWSZ), Wyższa Szkoła Prawa i Administracji w Przemyślu (dawna WSAiZ), Wyższa Szkoła Gospodarcza w Przemyślu, Wyższa Szkoła Informatyki i Zarządzania w Przemyślu, Wyższe Seminarium Duchowne w Przemyślu, Nauczycielskie Kolegium Języków Obcych w Przemyślu (do 30 września 2014 roku), Kolegium Nauczycielskie im. A. Fredry w Przemyślu; szacuje się, że w roku akademickim 2014/2015 liczba studentów w Przemyślu wyniosła1149 osób, zob. Raport o stanie Miasta Przemyśla, 2015: 94, http://bip.przemysl.pl/download/attachment/50877/raport-o-staniemiasta-przemysla.pdf, [20.04.2017]. 
w Przemyślu działało ok. 32 instytucje kultury. Rodzaje i liczbę głównych instytucji kultury w Przemyślu, wraz z ich procentowym udziałem wśród poszczególnych instytucji w regionie prezentuje poniższa tabela.

Tabela 1. Instytucje kultury w Przemyślu i województwie podkarpackim w 2012 roku

\begin{tabular}{|l|c|c|c|c|}
\hline Instytucja & Przemyśl & Region & $\begin{array}{c}\text { Region/ } \\
\text { Przemyśl } \\
{[\%]}\end{array}$ & $\begin{array}{c}\text { Liczba } \\
\text { korzystających } \\
\text { z oferty } \\
\text { instytucji/ } \\
\text { Przemyśl }\end{array}$ \\
\hline Placówki biblioteczne & 8 & 681 & 1,2 & 10483 \\
\hline Biblioteki naukowe, fachowe & 13 & 67 & 19,4 & 3885 \\
\hline Kina & 1 & 29 & 3,4 & 15501 \\
\hline Muzea łącznie z oddziałami & 4 & 43 & 9,3 & 41164 \\
\hline Teatr & 0 & 2 & 0,0 & b.d \\
\hline Filharmonia & 0 & 1 & 0,0 & b.d \\
\hline Galerie i salony sztuki & 1 & 7 & 14,3 & 660 \\
\hline $\begin{array}{l}\text { Domy i ośrodki kultury, kluby, } \\
\text { świetlice }\end{array}$ & 5 & 338 & 1,5 & 82675 \\
\hline
\end{tabular}

Źródło: opracowanie własne na podstawie: Bank Danych Lokalnych, http://www.stat.gov.pl/bdl/app/ strona.html?p_name=indeks, [20.10.2014].

Udział w wykorzystaniu instytucji kultury kształtuje się na poziomie stosunkowo wysokim w przypadku domów i ośrodków kultury oraz muzeów; przeciętnym w przypadku kina i bibliotek i niskim w przypadku galerii. Generalnie Przemyśl charakteryzuje się stosunkowo dużym zainteresowaniem mieszkańców uczestnictwem w kulturze. Przeciętna liczba uczestników imprez na 1 mieszkańca wynosi - podobnie jak w całym regionie - 1 . Tendencję tę potwierdzają również dane statystyczne uzyskane z Centrum Kultury i Nauki Zamek. Wynika z nich, że o ile w roku 2011 ta instytucja kultury zorganizowała 168 różnych wydarzeń kulturalnych, o tyle w roku 2013 liczba ta wyniosła 244 wydarzenia, w których udział wzięło blisko 56 tys. widzów i uczestników ${ }^{9}$. Dane GUS sugerują, że najchętniej mieszkańcy Przemyśla biorą udział w takich imprezach, jak: występy artystów i zespołów zawodowych oraz zespołów amatorskich.

9 Sprawozdanie z działalności Przemyskiego Centrum Kultury i Nauki ZAMEK w Przemyślu za 2013 rok. 
Tabela 2. Uczestnicy imprez organizowanych przez domy i ośrodki kultury, kluby i świetlice, 2012 rok

\begin{tabular}{|l|c|c|c|}
\hline Rodzaj imprezy & Liczba imprez & $\begin{array}{c}\text { Liczba } \\
\text { uczestników }\end{array}$ & $\begin{array}{c}\text { Odsetek } \\
\text { uczestników }\end{array}$ \\
\hline Seanse filmowe & 12 & 881 & 1,1 \\
\hline Wystawy & 45 & 2055 & 2,5 \\
\hline Występy zespołów amatorskich & 83 & 21836 & 26,4 \\
\hline $\begin{array}{l}\text { Występy artystów i zespołów } \\
\text { zawodowych }\end{array}$ & 80 & 26110 & 31,6 \\
\hline Dyskoteki & 4 & 200 & 0,2 \\
\hline Prelekcje, spotkania, wykłady & 94 & 334 & 0,4 \\
\hline $\begin{array}{l}\text { Imprezy turystyczne i sportowo- } \\
\text {-rekreacyjne }\end{array}$ & 8 & 598 & 0,7 \\
\hline Konkursy & 33 & 426 & 0,5 \\
\hline Inne & 445 & 82675 & 28,2 \\
\hline Ogółem & & & 100 \\
\hline
\end{tabular}

Źródło: opracowanie własne na podstawie: Bank Danych Lokalnych, http://www.stat.gov.pl/bdl/app/ strona.html?p_name=indeks, [20.10.2014].

Dokonana analiza danych zastanych wskazuje jednocześnie, że ważnym elementem życia kulturalnego miasta jest ruch amatorski. Skupia on 1341 osób, z czego jedną trzecią tworzą osoby dorosłe. Pole jego działalności obejmuje kolejno takie obszary kultury, jak: muzyka (515 osób), taniec (406), plastyka (293), teatr (97) oraz film i fotografię (41). Znaczący wpływ na kulturalny obraz miasta mają również stowarzyszenia społeczno-kulturalne, których $\mathrm{w}$ mieście działa przeszło $40^{10}$. Wśród nich znajduje się również kilka prowadzonych przez mniejszość ukraińską ${ }^{11}$ oraz jedno przez mniejszość romską ${ }^{12}$. Działalność wszystkich wymienionych instytucji, stowarzyszeń i placówek sprawia, że oferta kulturalna miasta jest bardzo bogata. Składa się na nią szereg imprez cyklicznych, które organizowane są od wielu lat i na stałe wpisały się w krajobraz miasta oraz mniejszych przedsięwzięć. Niektóre z nich mają charakter międzynarodowy, jak np. organizo-

10 Przykładowo są to: najstarsze: Towarzystwo Muzyczne działa od roku 1865, Towarzystwo Dramatyczne od roku 1869, a Towarzystwo Przyjaciół Nauk od 1909 roku oraz inne, jak: Galicyjskie Towarzystwo Genealogiczne, Grupa Rekonstrukcji Historycznych Artyleria, Południowo- Wschodni Instytut Naukowy, Przemyski Klub Fajki, Towarzystwo Miłośników Sztuki Sakralnej, Towarzystwo Przyjaciół Sztuk Pięknych; dane zebrane na podstawie [Raport o stanie miasta Przemyśla, 2015] Związek Ukraińców w Polsce - Oddział w Przemyślu, Ukraiński Dom Narodowy, Stowarzyszenie Ukraińskie Dziedzictwo.

12 Stowarzyszenie Romów Przemyskich. 
wane przez Przemyskie Towarzystwo Cyklistów Bike Town Przemyśl, które sprawiło, iż miasto uznawane jest za rowerową stolicę regionu. Na uwagę zwraca także fakt, że wiele $\mathrm{z}$ tych imprez organizowanych jest nie tylko w obszarze kultury „popularnej”, ale w równym stopniu i w obszarze kultury „wysokiej”. Wiele z organizowanych w Przemyślu wydarzeń wykorzystuje potencjał, jaki niesie ze sobą zróżnicowanie etniczne obszaru i bazując na historii oraz tradycji promują one w ten sposób dziedzictwo regionu. Spis ważniejszych wydarzeń i imprez zawiera tabela 3. Warto również dodać, że miasto Przemyśl prowadzi bardzo intensywne działania promocyjne, a ich efektem była wygrana IV polskiej edycji konkursu Komisji Europejskiej na „Najlepsze Europejskie Destynacje Turystyczne - EDEN”.

Bogata oferta wydarzeń kulturowych jest nie tylko wskaźnikiem zróżnicowanej działalności podmiotów w obszarze kultury, ale jest również wskaźnikiem ich wysokiej profesjonalizacji i indywidualizacji. Pozwala to na sformułowanie tezy, że ważnym elementem kapitału społeczno-kulturowego miasta są pasjonaci i różne stowarzyszenia oddolne, które działają w obszarze kultury. Być może jest to ten czynnik endogenny, który sprawia, że Przemyśl, jak wykazują badania zrealizowane przez Katarzynę Wojnar $^{13}$ [Wojnar 2015: 105-125] pomimo swego peryferyjnego położenia, jest miastem charakteryzującym się stosunkowo wysokim wskaźnikiem koncentracji kapitału kreatywnego (klasy kreatywnej) ${ }^{14}$, co zgodnie $\mathrm{z}$ teoretycznymi ustaleniami Richarda Floridy ma kluczowe znaczenie w procesie rozwoju i powstawania innowacji [Florida 2010]. Koncentracja klasy kreatywnej w mieście ma niewątpliwie przełożenie na liczebność i duże zróżnicowanie organizowanych w jego przestrzeni wydarzeń kulturalnych. Jednym z takich wydarzeń, jest poddana szczegółowej analizie wspomniana już Wincentiada.

13 Z badań przeprowadzonych przez K. Wojnar wynika, iż w kategorii miast atrakcyjnych, zdobywających przewagi konkurencyjne w postaci rosnącej koncentracji klasy kreatywnej w Polsce pojawiają się tylko cztery ośrodki: Krosno, Kraków, Poznań i właśnie Przemyśl; co więcej, Przemyśl osiąga wyniki powyżej średniej dla polskich miast i pod względem wartości wskaźnika dorównuje minimum Wrocławiowi. Co ciekawe, przytaczane badania wyraźnie wskazują, że do dynamicznych zmian w zakresie koncentracji kapitału kreatywnego w mieście doszło w dekadzie lat 2000, zwłaszcza po akcesji Polski do Unii Europejskiej. Należy wnioskować, że to właśnie wówczas pojawiły się możliwości strukturalne (finansowe instytucji kultury i samorządów), które wsparły inicjatywy twórcze.

14 Wskaźnikiem klasy kreatywnej jest udział pracowników zatrudnionych w kategoriach zawodowych należących do klasy kreatywnej w stosunku do liczby mieszkańców w wieku produkcyjnym. Natomiast podłoże kapitału kreatywnego stanowi założenie, że talent, wiedza i kreatywności ludzi stają się kluczowym zasobem w procesach produkcji opartych na wiedzy. Takie podejście zbieżne jest z założeniami Richarda Floridy na temat klasy kreatywnej, który konceptualizował ją nie w kategoriach ekonomicznych, a w kategoriach styl życia, modelu konsumpcji i nacechowanego pasją, twórczego stosunku do pracy [zob. Wojnar 2015: 57-65]. 
Tabela 3. Wybrane wydarzenia i imprezy składające się na ofertę kulturalną miasta, 2014

\begin{tabular}{|c|c|c|c|}
\hline Lp. & Rodzaj wydarzenia & Nazwa wydarzenia & $\begin{array}{l}\text { Uwzględnienie } \\
\text { czynnika } \\
\text { zróżnicowania } \\
\text { kulturowego } \\
\end{array}$ \\
\hline 1 & \multirow{11}{*}{ Muzyka } & Salezjańskie Lato Muzyczne & \\
\hline 2 & & $\begin{array}{l}\text { Koncert muzyki klezmerskiej organizowany } \\
\text { w ramach Ogólnopolskiego Dnia Judaizmu }\end{array}$ & \\
\hline 3 & & Międzynarodowe Warsztaty Gospel & \\
\hline 4 & & Ogólnopolski Festiwal Kapel Folkloru Miejskiego & \\
\hline 5 & & Świętojańska Noc Jazzowa & \\
\hline 6 & & $\begin{array}{l}\text { Międzynarodowy Kurs Interpretacji Muzyki } \\
\text { Wokalnej }\end{array}$ & \\
\hline 7 & & Jazz nad Sanem & \\
\hline 8 & & Festiwal Muzyki Akordeonowej & \\
\hline 9 & & Polsko-ukraiński festiwal „Jazz Bez...” & \\
\hline 10 & & „Scena Młodych” & \\
\hline 11 & & Finał Przemyskiej Sceny Niezależnej & \\
\hline 12 & \multirow{4}{*}{$\begin{array}{l}\text { Teatr. Literatura. } \\
\text { Poezja }\end{array}$} & „Zamkowe teatralia” & \\
\hline 13 & & Przemyska Wiosna Poetycka & \\
\hline 14 & & Przemyska Wiosna Fredrowska & \\
\hline 15 & & Bieszczadzkie Lato z Książką & \\
\hline 16 & \multirow[t]{3}{*}{ Sztuka. Malarstwo } & $\begin{array}{l}\text { Międzynarodowe Triennale Malarstwa Euroregionu } \\
\text { Karpaty „Srebrny Czworokąt” }\end{array}$ & \\
\hline 17 & & $\begin{array}{l}\text { Doroczna Nagroda Artystyczna im. Mariana } \\
\text { Strońskiego }\end{array}$ & \\
\hline 18 & & Festiwal Sztuki Sakralnej Pogranicza & \\
\hline 19 & \multirow[t]{2}{*}{ Taniec } & Ogólnopolski Turniej Tańca Towarzyskiego & \\
\hline 20 & & $\begin{array}{l}\text { Konfrontacje Dziecięcych i Młodzieżowych } \\
\text { Zespołów Tanecznych „Tańcowały dwa Michały” }\end{array}$ & \\
\hline 21 & Film & Festiwal Filmów Kina Niezależnego CK OFF & \\
\hline 22 & \multirow{8}{*}{$\begin{array}{l}\text { Imprezy plenerowe, } \\
\text { okolicznościowe } \\
\text { i inne }\end{array}$} & Piknik „Życia Podkarpackiego” & \\
\hline 23 & & Święto Zamku Kazimierzowskiego & \\
\hline 24 & & Święto Fajki & \\
\hline 25 & & Noc na Iwana Kupała & \\
\hline 26 & & Wielkie Manewry Szwejkowskie Twierdzy Przemyśl & \\
\hline 27 & & Europejskie Dni Dobrosąsiedztwa & \\
\hline 28 & & Przemyskie rekonstrukcje historyczne & \\
\hline 29 & & Wincentiada - Dni Patrona Miasta Przemyśla & \\
\hline
\end{tabular}




\section{Wincentiada - przemyskie święto miejskie}

Wincentiada jest odbywającym się corocznie świętem lokalnym organizowanym pod patronatem Prezydenta Miasta Przemyśla. Jest to impreza o charakterze masowym, odbywająca się $\mathrm{w}$ plenerze; zwykle $\mathrm{z}$ końcem sierpnia. W organizację święta zaangażowane są trzy zasadnicze podmioty: miejskie instytucje kultury, jak Wydział Kultury Urzędu Miasta i Przemyskie Centrum Kultury i Nauki „Zamek” oraz Kościół katolicki. Przedstawiciele Kościoła katolickiego reprezentują przy tym dwie instytucje: klasztor o. Franciszkanów, w którym znajdują się relikwie św. Wincentego, uznanego za patrona miasta oraz katolicką organizację charytatywną Caritas. Wiodącą czy wręcz dominującą rolę $\mathrm{w}$ organizacji wydarzenia odgrywa Centrum „Zamek”. Instytucja ta określa kształt i wizję projektu kulturowego, podejmuje decyzje merytoryczne oraz pełni funkcje koordynujące, nadzorujące i promocyjne. Znaczącym aktorem jest też kościół katolicki, który odpowiedzialny jest za przygotowanie religijnej oprawy święta oraz realizację charytatywnej akcji Caritas „Tornister pełen uśmiechów”15. Oprócz tego w organizację święta, niejako z własnej inicjatywy i/lub na zaproszenie organizatora włączają się inne, funkcjonujące w mieście instytucje i stowarzyszenia kulturalne. Istotnym czynnikiem może być tutaj fakt, że instytucje te charakteryzuje różnorodność prowadzonych projektów oraz stosunkowo wysoki stopień profesjonalizacji i niezależności działań. Spośród instytucji lokalnych, we współpracę przy organizacji wydarzenia zaangażowane są głównie miejskie instytucje kultury oraz te organizacje i stowarzyszenia społeczno-kulturowe i grupy artystyczne, z którymi nawiązywano już współpracę w przeszłości i/lub przy okazji innych wydarzeń kulturalnych (np. Fredreum, Przemyska Fundacja Rozwoju Tańca, Stowarzyszenie Sztuki Sakralnej). Sieć współpracy, tworzona na potrzeby organizacji święta, obejmuje również: przedsiębiorców aktywnych w sektorze kultury (cechy rzemiosł, kupców, producentów lokalnych wyrobów), lokalnych partnerów biznesowych (np. lokalne spółki), organizacje przeznaczone do ochrony bezpieczeństwa ludzi i mienia (Policja, Straż Miejska, Straż Pożarna), a także lokalne media. Niejako na własną rękę w obchody święta włączają się przedstawiciele przemyskiego Towarzystwa Miłośników Dobrego

15 Akcja charytatywna Caritas „Tornister pełen uśmiechów” została po raz pierwszy włączona w obchody Wincentiady w 2013 roku. Z udzielonych informacji wynika, że głównym motywem połączenia wydarzeń był tu ogólnopolski charakter akcji Caritas i co za tym idzie możliwość promocji miasta w skali kraju oraz chęć zmniejszenia kosztów finansowych związanych z organizacją imprez w różnych terminach. 
Wojaka Szwejka, w skrócie nazywanego „Szwejkami”. Chociaż zarysowany tu obraz świata instytucji przemyskiej kultury sprawiać może wrażenie świata niezintegrowanego, to do końca tak nie jest. Badania jasno wskazują bowiem, że zwornikiem łączącym działania instytucji jest tu bardzo silna identyfikacja $\mathrm{z}$ miastem oraz związane $\mathrm{z}$ nią przekonanie o jego wyjątkowości, swego rodzaju elityzmie i znaczącej roli kultury w jego przestrzeni. W sieć współpracy w ramach organizacji badanego wydarzenia kulturalnego zaangażowane są również instytucje o charakterze ponadlokalnym; są to głównie stowarzyszenia prowadzące działalność artystyczną (np. Teatr Gry Ulicznej, Diamond Klub, Kataryniarze), przedsiębiorcy aktywni w sektorze kultury (wystawcy), partnerzy biznesowi - sponsorzy (PGE oraz banki), a także ponadlokalne media: Telewizja Rzeszów oraz Telewizja Polska.

Obraz Wincentiady jaki wyłania się z przeprowadzonych badań, wyraźnie wskazuje na mieszany: religijno-świecki charakter święta. Z jednej strony Wincentiada to święto obchodów dni patrona miasta Przemyśla św. Wincentego; z drugiej strony jarmarczny i festynowych charakter obchodów nadają mu cech świeckości. Z uzyskanych informacji wynika, że historia wydarzenia sięga XVII wieku. Organizację uroczystości obchodów przerwała II wojna światowa oraz późniejsze nastanie systemu komunistycznego. W okresie komunistycznym odbywały się uroczystości ku czci św. Wincentego, ale miały wyłącznie religijny charakter związany z kościołem oo. Franciszkanów. Dopiero zmiany ustrojowe sprawiły, że na początku lat dziewięćdziesiątych XX wieku (podawana jest data 1990 rok) powrócono w Przemyślu do idei organizacji święta. Zauważyć przy tym należy, że w swojej formie święta lokalnego miało ono od początku dwa wzory. Po pierwsze, ogólny, związany z organizacją w czasach PRL-u tzw. Dni Miasta, które miały dość rozbudowaną strukturę (wiele imprez o różnym charakterze), lecz przeciętną popularność w latach 80. XX wieku. Po drugie, szczególny, związany z inspiracją dla przemyskich organizatorów, jaką były kontakt z miastem partnerskim Paderborn w Niemczech. Lokalne znaczenie święta wzrosło dopiero ok. 2005 roku, co można wiązać z polityką promocji miasta przez władze miejskie i odwołaniem się osób zarządzających lokalną kulturą do popularnych już wzorów jarmarków lokalnych w dużych miastach: Jarmarku Dominikańskiego w Gdańsku i Świętego Marcina w Poznaniu. Obecnie główne obchody odbywają się w ostatnią niedzielę sierpnia; rozpoczynają je uroczystości religijne, a kończą koncerty muzyki rozrywkowej przeznaczone dla szerokiego grona odbiorców. Poszczególne edycje święta różnią się pewnymi szczegółami oraz bogactwem i rodzajem imprez towarzyszących. 
Główną osią, na podstawie której tworzona jest obecna koncepcja święta są obowiązujące w społeczności lokalnej sposoby jego definiowania oraz przypisywana mu rola. Dają się przy tym wyróżnić następujące, główne elementy definicyjne wydarzenia: nawiązanie do tradycji mieszczańskiej, nawiązanie do tradycji lokalnej ${ }^{16}$, święto miasta, święto mieszkańców, święto przemyskie. Co ciekawe, w wypowiedziach odnoszących się do sposobów definiowania święta rzadko akcentowany był fakt zróżnicowania etnicznego i kulturowego miasta. Skupiano raczej uwagę na tym co miejskie-lokalne; nie włączając w to tradycji pluralistycznych tego obszaru ${ }^{17}$. Ów silny akcent lokalności pojawia się również $\mathrm{w}$ wielu wydarzeniach towarzyszących imprezie; m.in. w ramach "otwartych drzwi” miejskiego Ratuszu, w trakcie których Prezydent Miasta podkreślał wzrastające znaczenie Wincentiady jako święta miasta. Pojawił się również w trakcie zorganizowanej w ramach imprezy promocji książki, pochodzącego z Przemyśla, historyka, wykładowcy Uniwersytetu Jagiellońskiego w Krakowie. Wystąpienie prowadzącego podkreślało lokalny kontekst spotkania, czego wskaźnikami było m.in.: podkreślanie lokalnego zakorzenienia autora książki: „oto nasz rodak, wychowanek naszego liceum, osoba mocno zakorzeniona"; czy też używanie terminów „nasz”, „nasze” w kontekstach lokalnych. Generalnie pod względem organizacji Wincentiada jest świętem wieloetapowym (część religijna; piknik rodzinny; impreza masowa) i rozbudowanym w przestrzeni miasta. Oznacza to, że odbywa się ona w ścisłym centrum miasta: w jego najbardziej historycznej i reprezentatywnej części - w Rynku Starego Miasta ${ }^{18}$ oraz przyległych do niego ulicach Franciszkańskiej

16 Wart odnotowania jest fakt, że w jednej wypowiedzi pojawiało się przy tym przekonanie, że „najbardziej popularną jest tradycja Austrii, zaborów i Twierdzy Przemyśl. To jest taka najbardziej istniejąca w świadomości”(B), co z wielką dozą ostrożności można interpretować w kierunku swego rodzaju kultywowania w społeczności lokalnej tradycji galicyjskiej.

17 Czynnik zróżnicowania kulturowego uwzględniany jest natomiast w planach organizatorów odnośnie przyszłych edycji Wincentiady. Z deklaracji jednej z rozmówczyń wynika bowiem, że pojawiała się wśród organizatorów idea zaaranżowania w trakcie trwania Wincentiady specjalnego oświetlenia („historia światłem malowana”), za pomocą którego odtworzono by historię budynków: katedry rzymskokatolickiej, greckokatolickiej i synagogi jako symboli dziedzictwa miasta. Realizacja tych planów uzależniona jest oczywiście od możliwości finansowych instytucji. Godne uwagi jest również to, że badania wyraźnie wskazują, iż pluralizm kulturowy i etniczny uwzględniany jest w szeregu innych działań podejmowanych przez badane instytucje. Łączy się to nie tylko z szeroko pojętą promocją dziedzictwa pluralizmu kulturowego (chociażby przez wspomniane już Triennale czy organizacją Dni Dobrosąsiedztwa), ale z podejmowaniem szeregu wspólnych działań np. zapraszaniem ukraińskich czy słowackich artystów oraz uczestnictwem w organizowanej przez społeczność ukraińską w Przemyślu Nocy Kupały.

18 Charakteryzuje się on: renesansową zabudowę; XIX-wieczną zabudową ulic, barokowymi zabytkami miejskimi (kościół franciszkanów, wieża zegarowa;); występowaniem pomników o znaczeniu narodowym, religijnym i lokalnym (Mickiewicza, Sobieskiego, Jana Pawła II, Wojaka Szwejka, fajki, fontanną z Niedźwiadkam). 
i Kazimierzowskiej. W roku 2013 uczestniczyło w niej ok. 20 tysięcy widzów ${ }^{19}$, co pozwala na uznanie wydarzenia jako dużego w skali miasta. Struktura demograficzna uczestników Wincntiady jest zróżnicowana. Biorą w nim udział osoby o zróżnicowanej strukturze wiekowej i strukturze płci. Przeprowadzone w ramach projektu badania ankietowe wśród 84 uczestników wydarzenia pozwalają dodatkowo zauważyć, że zdecydowaną większość stanowią mieszkańcy Przemyśla (82\%), posiadający wykształcenie średnie (41\%) lub wyższe (40\%), w znacznie mniejszej liczbie osoby o zawodowym (13\%) lub niższym poziomie wykształcenia (6\%). Do pozostałych uczestników wydarzenia zaliczyć można wystawców (w tym lokalnych producentów żywności), artystów, przedstawicieli instytucji publicznych oraz stowarzyszeń społeczno-kulturalnych. Poniżej prezentujemy kalendarium Wincentiady.

\section{KALENDARIUM WINCENTIADY 2013}

\section{4 sierpnia, sobota}

IMPREZY TOWARZYSZĄCE

$09.00-$

Mecz piłki nożnej o Puchar Prezydenta Miasta Przemyśla Drużyny: Samorząd, Prawo (Stadion Polonii)

10.00 - Wycieczka z przewodnikiem PTTK pt.: „Święty Wincenty w Kościele Franciszkanów" (miejsce zbiórki - Rynek Starego Miasta koło fontanny)

16.00 - $\quad 18.00$ - Gabinet Prezydenta i sala narad otwarte dla mieszkańców

18.00 - Promocja książki dr. Tomasza Pudłockiego pt.: „Będziemy działać”. Wincenta Tarnawska w służbie niepodległości Polski („Piwnica Artystyczna pod Niedźwiadkiem")

20.00 - Chorały gregoriańskie i poezja Karmelu w wykonaniu zespołu „Twoje Niebo" (Kościół Franciszkanów)

25 sierpnia niedziela, Rynek Starego Miasta

GŁÓWNE OBCHODY

10.00 - Msza Święta w Kościele Franciszkanów w intencji Przemyśla. Wystawienie relikwii Świętego Wincentego, po mszy procesja ulicami Miasta

12.00 - Rozpoczęcie JARMARKU ŚWIĘTEGo WINCENTEGo

ok. 12.05 - $\quad$ Powitanie dzieci przez Prezydenta Miasta Przemyśla, Gwardiana Klasztoru Franciszkanów, Dyrektora Caritas Polska

19 Dane uzyskane od organizatorów. 
W bloku scenicznym wystąpili:

Młodzieżowa Orkiestra Dęta z Łańcuta, Teatr „Pinokio” ze Starego Sącza, zespoły wokalno-instrumentalne 5 BSP, „Teatr Gry Wstępnej” z Wrocławia, Tomasz Drabina - AVIACCORD w duecie z Krakowa, Scena Komediowa PCKiN ZAMEK, TRUE GROUP, Szkoła Tańca A-Z

ok. 16.00 - $\quad$ Przekazanie tornistrów dzieciom

ok. 17.00 - Parada uliczna

ok. 17:15 - Pozdrowienie uczestników WINCENTIADY przez organizatorów WIECZORNY BLOK IMPREZOWY

od 17.30 - $\quad$ wystąpili: zespół „Dusza we Mgle”, Monika Kuszyńska z zespołem, Kasia Kowalska z zespołem

FINAE

ok. 22.00 - Pokaz laserowo-multimedialny Visual Sensation

INNE IMPREZY TOWARZYSZĄCE (NIEDZIELA)

12.00-17.00 - V Przemyska Gra Miejska (początek i finał „Piwnica Artystyczna pod Niedźwiadkiem”),

„Dzieciaki malujemy buziaki” oraz wiele innych atrakcji w Rynku Starego Miasta przygotowanych przez pracownię plastyczną MDK, Świetlicę „Wzrastanie”

12.30-17.30 - Promocja zdrowego stylu życia z „DIAMOND CLUB” (ul. Kazimierzowska)

15.00 - Warsztaty ikonograficzne dla dzieci - Towarzystwo Miłośników Sztuki Sakralnej (Klasztor Karmelitów Bosych)

16.00 - Spektakl „Oświadczyny” - Teatr „Fredreum”(„Piwnica Artystyczna pod Niedźwiadkiem”)

18.00 - Promocja książki „Sztuka sakralna pogranicza” - Towarzystwo Miłośników Sztuki Sakralnej (Klasztor Karmelitów Bosych)

\section{Społeczno-kulturowa charakterystyka miasta Sanok}

\section{Historia i współczesność}

Sanok jest miastem powiatowym, położonym w południowo - wschodniej części województwa podkarpackiego. Jest siedzibą powiatu sanockiego i gminy wiejskiej Sanok. Położone w Dolinie Sanu w Kotlinie Sanockiej, w pobliżu granicy ze Słowacją i Ukrainą. Ze względu na swoje położenie geograficzne nazywane jest „bramą Bieszczadów”20. Historia Sanoka jako

20 Dane GUS z 2012 roku, Statystyczne Vademecum Samorządowca 2016 , Urząd Statystyczny w Rzeszowie, www. rzeszow.stat.gov.pl/vademecum, [16.03.2017]. 
miasta sięga 1339 roku, kiedy to książę halicko-wołyński Jerzy II nadał przywilej lokacyjny na prawie magdeburskim miejscowości, korzystnie położonej na skrzyżowaniu szlaków handlowych na Ruś i Węgry. Po roku 1340 Kazimierz Wielki przyłączył do Polski Ruś Halicką, w 1366 roku potwierdził prawa miejskie Sanoka. Sanok stał się stolicą jednostki administracyjnej o nazwie Ziemia Sanocka, która weszła w skład województwa ruskiego. W sanockim zamku miał siedzibę urząd grodzki i ziemski, ze starostą na czele. W mieście działały również sądy: grodzki, ziemski i wyższy sąd prawa niemieckiego dla Ziemi Sanockiej [Leśniak 1995: 115]. W mieście mieszkali Polacy i Węgrzy, ale „... dawni mieszkańcy grodu sanockiego i osad okolicznych byli w przeważającej części pochodzenia ruskiego i w czasie panowania książąt kijowskich oraz halicko-włodzimierskich charakter ruski grodu sanockiego nie da się zakwestionować”[Kiryk 1995: 93]. Proporcje te zaczęły ulegać zmianie wraz z postępem kolonizacji na prawie czynszowym.

Największy rozkwit miasta miał miejsce od połowy XIV wieku do połowy XVI wieku. Z tego okresu pochodzi zamek sanocki. Sanok był miastem królewskim - wiązało się to z obowiązkami dla mieszkańców, ale też przynosiło korzyści wynikające z przywilejów nadawanych przez kolejnych monarchów, zwłaszcza z dynastii Jagiellonów. Umiejscowienie urzędów i sądów otwierało przed mieszkańcami możliwości zarobkowania: „liczne i częste odwiedziny obcych, klienteli tutejszych urzędów, stwarzały mieszkańcom miasta okazję do bogacenia się na ich obsłudze" [Leśniak 1995: 115]. Ówczesny Sanok wydał dwóch znakomitych przedstawicieli polskiego odrodzenia: Grzegorza z Sanoka i Jan Grodka. W drugiej połowie XVI wieku rozpoczął się upadek miasta, postępujący w wieku XVII [Kiryk 1995: 112]. Pod koniec XVIII wieku Sanok liczył ok. 1500 mieszkańców. Według szacunków historyków, miasto zamieszkiwało wówczas ok. 220 „ludności rzymskokatolickiej”, osób, „ludności wyznania grekokatolickiego" - ok. 700 osób, a ludności wyznania mojżeszowego - ok. 390 osób [Kiryk, Leśniak 1995: 211]. Osadnictwo żydowskie w Sanoku rozpoczęło się stosunkowo późno - od XVI wieku ale „odtąd żywioł żydowski stawał się trwałym elementem miejskiej społeczności sanockiej" [Kiryk, Leśniak 1995: 222].

W roku 1772, w wyniku I rozbioru Polski Sanok oraz ziemia sanocka weszły w skład Królestwa Galicji i Lodomerii. Miasto pełniło funkcje ośrodka administracyjnego. W okresie zaborów w mieście zostały zapoczątkowane przedsięwzięcia, które miały zasadniczy wpływ na jego kierunki rozwoju i współczesną charakterystykę. Pierwszym z nich było założenie przez Mateusza Beksińskiego i Walentego Lipińskiego kowalsko-kotlarskiego zakładu 
rzemieślniczego, w którym rozpoczęto produkcję kotłów, narzędzi miedzianych i innych przedmiotów użytkowych. Z czasem, w związku z odkryciem złóż ropy naftowej, uruchomiono w nim produkcję narzędzi i urządzeń dla górnictwa i przemysłu naftowego, przemysłu gorzelniczego i browarnictwa. W roku 1886 warsztat został przemianowany na zakład przemysłowy. Kazimierz Lipiński (syn Walentego) założył w kilka lat później Pierwsze Galicyjskie Towarzystwo Budowy Maszyn i Wagonów w Sanoku i w latach 1894-1895 przystąpił do budowy fabryki. Duże znaczenie dla rozwoju miasta miało wybudowanie w 1872 roku linii kolejowej z Chyrowa przez Zagórz i Łupków na Węgry oraz w 1884 roku wykonanie odcinka z Zagórza przez Sanok, do Jasła [Opas 1995: 320]. Po reformie administracyjnej w roku 1864 Sanok był siedzibą starostwa i powiatu sądowego w kraju Galicja. W dziedzinie kultury istotne znaczenie miała działalność Karola Pollaka, który w 1848 roku założył drukarnię, a w 1861 roku księgarnię i wypożyczalnię książek. W roku 1855 wydrukowano pierwszy zeszyt „Biblioteki Polskiej” redagowany przez Kazimierza Józefa Turowskiego [Opas 1995: 320]. W 1880 roku w Sanoku powstało Gimnazjum [Sołtys 1995: 435], działało tu też Towarzystwo Gimnastyczne Sokół i inne stowarzyszenia, takie jak konfraternie rzemieślnicze, bractwa religijne, Towarzystwo Kulturalno-Oświatowe „Czytelnia Miejska” i Towarzystwo Kassynowe [Opas 1995: 323-324]. W roku 1883 miasto liczyło ok. 5 tysięcy mieszkańców, w tym 4 tysiące Polaków (w liczbę tę włączano również Żydów), 550 Rusinów, 270 Niemców i 21 osób innych narodowości [Opas 1995: 345].

W okresie międzywojennym życie gospodarcze miasta wzbogaciło się o trzy nowe fabryki: Fabrykę Gum, Fabrykę Obrabiarek i Fabrykę Wagonów, z czego dwie pierwsze obrabiarek zostało włączone do Centralnego Okręgu Przemysłowego. [Sołtys 1995: 530, 532, 534]. W Sanoku funkcjonowało 5 szkół powszechnych, istniejące wcześniej gimnazjum zostało przekształcone w Państwowe Gimnazjum Męskie im Królowej Zofii. [Zając 1995: 596]. W 1938 roku miasto zamieszkiwało 8573 rzymskich katolików, 1415 grekokatolików i 4773 wyznawców judaizmu [Sołtys 1995: 543]. Grupy narodowościowe miały swoich liderów i prowadziły osobną działalność społeczno - kulturową, ale nie było między nimi poważniejszych konfliktów: „każda grupa narodowościowa w mieście działała we własnym kręgu ale uczestniczyła także we wspólnych poczynaniach kulturalnych" [Zając 1995: 623]. W 1931 roku powstało Muzeum Regionalne Łemkiwszczyzna, a w 1934 roku, (z inicjatywy Ministerstwa Wyznań Religijnych i Oświecenia Publicznego), utworzone zostało przez Towarzystwo Przyjaciół Ziemi Sanockiej Muzeum Ziemi Sanockiej [Zając 1995: 613-615]. W 1936 roku 
Sanok był gospodarzem największej w swoich dotychczasowych dziejach imprezy kulturalnej - Zjazdu Ziem Górskich [Zając 1995: 624-625].

W latach II wojny światowej Sanok znajdował się w granicach Generalnego Gubernatorstwa. Jak pisze Jacek Chrobaczyński, „wybuch wojny zaostrzył w znacznym stopniu konflikt polsko-ukraiński... wojna zaktywizowała w Sanoku i najbliższym regionie środowiska nacjonalistów ukraińskich" [1995: 635] W okresie okupacji zagładzie ulegli prawie wszyscy żydowscy mieszkańcy miasta, którzy przed wojną stanowili ok. 30\% jego ludności [Chrobaczyński 1995: 647]. Mieszkańcy Sanoka i okolic angażowali się w działalność konspiracyjną. Przez Sanok prowadziły w latach 1940-1942 trasy kurierskie na Węgry, prowadzone były również przez AK liczne akcje dywersyjne. Wkroczenie Armii Czerwonej w 1944 roku przyniosło miastu znaczne straty gospodarcze. Ziemia Sanocka stała się areną wojny domowej pomiędzy ukraińskim podziemiem a oddziałami MO, SB i Wojska Polskiego, która trwała do 1948 roku. Jej ostatnim aktem były przesiedlanie ukraińskojęzycznej ludności Sanocczyzny w ramach Akcji Wisła. Po zakończeniu II wojny światowej okolice Sanoka były też areną walk sił nowego systemu $\mathrm{z}$ antykomunistycznymi oddziałami partyzanckimi [Brygidyn 1995: 753-761].

W okresie PRL nastąpiła odbudowa, a następnie rozbudowa zakładów przemysłowych Sanoka i ich reorganizacja zgodnie z zasadami gospodarki socjalistycznej. Największe przedsiębiorstwa tego okresu: Sanocka Fabryka Autobusów „Autosan” i Zakłady Przemysłu Gumowego „Stomil”, zatrudniające tysiące pracowników, zdobyły pozycję głównych podmiotów rozwoju miasta. Wokół starej części Sanoka powstały nowe osiedla mieszkaniowe, liczba mieszkańców osiągnęła ponad 22 tysiące na początku lat 70. XX wieku, w stosunku do ok. 10 tysięcy mieszkańców po II wojnie światowej). Sanok stał się istotnym ośrodkiem przemysłowym, rozpoznawanym w Polsce [Stachowicz 1995: 805-854].

Współczesny Sanok liczy 38486 mieszkańców, jego powierzchnia wynosi $38 \mathrm{~km}^{2}$. Najwięcej mieszkańców jest zatrudnionych w przemyśle. Stosunkowo duża liczba osób pracuje w sektorach ochrony zdrowia i opieki społecznej oraz edukacji i administracji, co wiąże się z funkcją lokalnego centrum administracyjno-gospodarczego, jaką pełni miasto ${ }^{21}$. Bezrobocie wynosi $8,1 \%^{22}$. Dokument miejski „Diagnoza sytuacji społeczno-gospodar-

\footnotetext{
Serwis UM Sanoka, www.sanok.pl, [16.03.2017].

22 Dane GUS z 2012 roku, Statystyczne Vademecum Samorządowca 2016, Urząd Statystyczny w Rzeszowie, www. rzeszow.stat.gov.pl/vademecum, [16.03.2017].
} 
czej Miasta (jakościowa). Zrównoważona Strategia Rozwoju Miasta Sanoka na lata 2013-2024" zawiera zestaw najpoważniejszych słabości miasta w dziedzinie gospodarczej. Należą do nich m.in.: słabo rozwinięty rynek pracy, małe szanse na znalezienie pracy w Sanoku w swoim zawodzie, odpływ młodych wykwalifikowanych ludzi za granicę, niski poziom przedsiębiorczości (liczba podmiotów gospodarczych na 1000 mieszkańców w Sanoku jest niższa od średniej notowanej w miastach porównywalnych), przewaga przedsiębiorstw zatrudniających do 9 pracowników (95\%), [Diagnoza..., 2013: 15,25].

Najważniejsze i najstarsze zakłady przemysłowe Sanoka, to: Fabryka Autobusów „Autosan” S.A., Sanok Rubber Company S.A. (do 2015 roku: Sanockie Zakłady Przemysłu Gumowego „Stomil Sanok” S.A.) Produkcja autobusów w „Autosanie” rozpoczęła się w latach 50. ubiegłego wieku. W okresie PRL zatrudnienie sięgało ok. 7 tysiecy osób. W latach 1950-1990 „Autosan” produkował na potrzeb kraju duże partie tanich autobusów; w 1990 roku, po restrukturyzacji, znacznie obniżył się poziom zatrudnienia i rozpoczął się okres walki o przetrwanie. 30 marca 2016 roku, w obecności Premier B. Szydło, oficjalnie podpisano akt, na mocy którego właścicielem przedsiębiorstwa Autosan zostało konsorcjum spółek PIT - RADWAR i HUTA Stalowa Wola, należących do Polskiej Grupy Zbrojeniowej ${ }^{23}$. Sanockie Zakłady Przemysłu Gumowego "Stomil Sanok” S.A. powstały w 1932 roku jako jedna z inwestycji Centralnego Okręgu Przemysłowego. W okresie PRL byłą drugą największą firmą produkcyjną w mieście. W 2015 roku spółka zmieniła nazwę. Inne ważne firmy działające w Sanoku to przede wszystkim: Sanocki Zakład Górnictwa Nafty i Gazu, Zakłady Mięsne „Beef-San” oraz Ciarko (producent okapów dachowych).

O specyfice miasta decyduje też lokalna scena polityczna. Od roku 2014 funkcję burmistrza Sanoka pełni Tadeusz Pióro, przedstawiciel Prawa i Sprawiedliwości. W II turze wyborów pokonał on urzędującego (od 2002 roku) burmistrza, Wojciecha Blecharczyka, startującego z ramienia Komitetu Wyborców Wojciecha Blecharczyka - Dla Sanoka. Komitet Wyborczy PiS wygrał także wybory do Rady Miasta, do której wprowadził 9 radnych. W Radzie Miasta Sanoka zasiada ponadto 5 radnych z Komitetu Wyborców Wojciecha Blecharczyka - Dla Sanoka, 2 - z KW Samorządu Ziemi Sanockiej i po 1 przedstawicielu: KW Wyborców Ruchu Narodowego, KW Towarzystwa Przyjaciół Sanoka i Ziemi Sanockiej, KW Wyborców Ruch Samorządowy Na Rzecz Rozwoju Sanoka, KW Wyborców Niezrzeszeni

23 www.autosan.eu, [16.03.2017]. 
dla Rozwoju Sanoka, KW Wyborców Macieja Drwięgi. W Radzie Powiatu Sanockiego zasiada najwięcej przedstawicieli PiS i PSL - po 6 osób. Pozostali radni powiatowi to reprezentanci: Stowarzyszenia „Zjednoczeni Samorządowcy Ziemi Sanockiej” (3 osoby), Platformy Obywatelskiej (3 osoby) i Towarzystwa Przyjaciół Sanoka i Ziemi Sanockiej (3 osoby). Funkcję starosty pełni Roman Konieczny z PiS.

Sanok i Ziemia Sanocka były i są miejscem współwystępowania różnych narodowości i kultur. We współczesnym Sanoku żyje ok. 100 osób narodowości ukraińskiej. Działają w organizacjach przy prawosławnej parafii katedralnej. Istnieje także Oddział Związku Ukraińców w Polsce. Najbardziej rozpoznawalną działaczką jest Marianna Jara. Najbardziej znanym zespołem artystycznym jest Widymo. W latach 1983-2016 Sanok był siedzibą władyki prawosławnej eparchii przemysko-nowosądeckiej ${ }^{24}$. Zróżnicowanie religijne współczesnego Sanoka obrazuje zestawienie głównych świątyń. W mieście funkcjonuje pięć parafii rzymskokatolickich (Parafia Przemienienia Pańskiego, Kościół pw. Chrystusa Króla, Kościół O.O. Franciszkanów, Parafia Najświętszego Serca Pana Jezusa, Parafia Narodzenia NMP); parafia Kościoła greckokatolickiego (Parafia Świętego Dymitra), parafia prawosławna (Parafia katedralna Świętej Trójcy), parafia polskokatolicka (Parafia Matki Bożej Różańcowej) oraz wspólnoty protestanckie: Ewangeliczna Wspólnota Zielonoświątkowa i Zbór Kościoła Adwentystów Dnia Siódmego. W Sanoku narodził się pomysł spotkań ekumenicznych wiernych i duchownych wszystkich wyznań. Tradycja tych spotkań rozpoczęła się w 1998 roku, z inicjatywy osób świeckich z Kościołów prawosławnego i rzymskokatolickiego. Promotorem tych spotkań był franciszkanin, o. Stanisław Glista. Brali w nich udział duchowni i wierni wszystkich wyznań w Sanoku. W ramach spotkań ekumenicznych zorganizowano w Sanoku festiwal muzyczno-artystyczny: „Jeden Bóg - Wiele Kultur”. Miał on dwie edycje - w 2007 i 2008 roku. W ciągu czterech dni prezentowano cztery tradycje, od wieków obecne na ziemi sanockiej: prawosławną, katolicką, protestancką i żydowską ${ }^{25}$.

Edukacja. W Sanoku funkcjonuje 7 szkół podstawowych, 5 gimnazjów (do 2017 roku), 5 zespołów szkół ponadgimnazjalnych i w sumie 8 liceów ogólnokształcących (w tym 1 dla dorosłych). Szkolnictwo artystyczne reprezentuje Państwowa Szkoła Muzyczna I i II stopnia. Sanockie szkoły wyższe to: Nauczycielskie Kolegium Języków Obcych, Państwowa Wyższa

24 Serwis UM Sanoka, www.sanok.pl, [16.03.2017]. 
Szkoła Zawodowa im. Jana Grodka, Podkarpacka Szkoła Przedsiębiorczości i Policealne studium pielęgniarskie.

Sport. Największe tradycje i sukcesy sportowe Sanoka wiążą się z hokejem, łyżwiarstwem szybkim i piłką nożną. Najbardziej utytułowany jest klub hokejowy Ciarko PBS Bank Sanok, powstały w 1958, roku w przeszłości działający pod nazwami Stal, STS, SKH, KH, Ciarko KH). W ostatniej dekadzie klub dwukrotnie zdobywał Mistrzostwo Polski (w latach 2012 i 2014) i Puchar Polski (w latach 2010 i 2011). W sezonie 2016/2017 klub zawiesił udział w rozgrywkach ligowych $\mathrm{z}$ powodu trudności organizacyjnych i finansowych. Obecnie podejmowane są starania o powrót do gry, pod zmienioną nazwą Sanockie Towarzystwo Sportowe S.A. [Błażejewski 2007]. W Sanoku funkcjonują też 3 kluby łyżwiarstwa szybkiego, z których wywodzą się czołowi zawodnicy krajowi i reprezentanci Polski. Głównym podmiotem odpowiedzialnym za sport i rekreację w mieście jest Miejski Ośrodek Sportu i Rekreacji (MOSiR), założony w 1965 roku. Pod jego egidą funkcjonuje tor łyżwiarski Błonie oraz hala widowiskowo-sportowa z lodowiskiem Arena Sanok (otwarty w 2006 roku). Jest to jedna z najnowocześniejszych hal sportowych w Polsce. Może pomieścić do 5 tysięcy osób (miejsc siedzących ok. 3 tysiace). Hala jest również wyposażona w scenę do organizowania koncertów. Funkcjonowanie hali z lodowiskiem umożliwia organizowanie imprez łyżwiarskich, także międzynarodowych. Inne obiekty sportowe (stadion miejski Wierchy, stadion Stali Sanok, zespół basenów kąpielowych, korty tenisowe, trzy obiekty powstałe w ramach programu Orlik 2012), które znajdują się w mieście stanowią bazę infrastrukturalną dla sportowców wyczynowych i amatorów, w takich dyscyplinach, jak przede wszystkim piłka nożna (obok hokeja i łyżwiarstwa najpopularniejsza w mieście), siatkówka, pływanie, tenis, sporty walki. W Sanoku ma także swoją siedzibę Bieszczadzkie Towarzystwo Żeglarskie.

\section{Lokalne zasoby kultury}

Najważniejsze instytucje kultury Sanoka, to: Muzeum Historyczne, Muzeum Budownictwa Ludowego, Miejska Biblioteka Publiczna im. Grzegorza z Sanoka i BWA Galeria Sanocka. Muzeum Historyczne, istnieje od 1934 roku. Posiada największą w Europie kolekcję ponad 700 ikon z XV-XIX wieku oraz wystawę twórczości Zdzisława Beksińskiego. Muzeum prowadzi też działalność edukacyjną i artystyczną. Muzeum Budownictwa Ludowego (skansen), założone w 1958 roku, jest największym w Polsce i jednym z największych w Europie obiektów tego typu. Gromadzi zabytki architektury ludowej wraz z wyposażeniem. Szczególne atrakcje skansenu stanowią: 
ekspozycja malarstwa cerkiewnego (XVI-XIX wiek) oraz zrekonstruowany Rynek Galicyjski. Przy Muzeum działa też biblioteka [Oberc 1999]. Miejska Biblioteka Publiczna posiada bogate zbiory literatury dotyczącej Sanoka i Ziemi Sanockiej. Prowadzi także działalność wydawniczą, zorientowaną na miejscowych twórców oraz lokalną historię, kulturę i współczesność. Prowadzi także działalność popularyzującą czytelnictwo oraz dyskusyjne kluby książki. W Miejskiej Bibliotece Publicznej znajduje się bogaty dział: Bibliografia Sanoka i Powiatu Sanockiego ${ }^{26}$. Biuro Wystaw Artystycznych Galeria Sanocka - powstała w maju 2006 roku, jest niekomercyjną instytucją miejską. Poza organizacją wystaw prowadzi działalność edukacyjną w zakresie historii sztuki, przeglądy filmów, teatr młodzieżowy, zajęcia artystyczne dla dzieci.

W Sanoku działają także domy kultury: Sanocki Dom Kultury, Młodzieżowy Dom Kultury, Osiedlowy Dom Kultury „Gagatek”, Osiedlowy Dom Kultury „Puchatek”, Dom Kultury Caritas.

Artyści i animatorzy kultury tworzą w Sanoku środowiska, podejmujące inicjatywy kulturalne. Przykładem może być działanie muzycznego Klubu PaniK w pierwszej dekadzie lat 2000 XXI wieku i przedsięwzięcie Stacja Sanok Miasto - mające na celu stworzenie miejsca spotkań i działań artystycznych w obiektach dawnej stacji kolejowej, przekazanej przez władze miasta Kolektywowi Artystycznemu „Sanok Miasto”. Liczne stowarzyszenia działające w Sanoku koncentrują się wokół różnorakich celów i problemów. Biorąc pod uwagę dziedziny zainteresowań i form działalności można wśród nich wyróżnić: stowarzyszenia miłośników i przyjaciół społeczności lokalnej, stowarzyszenia kulturalne i artystyczne, stowarzyszenia turystyczne, ekologiczne, oświatowe, hobbystyczne, kombatanckie, stowarzyszenia przedsiębiorców lokalnych, charytatywne, samopomocowe i liczne kluby sportowe. Z punktu widzenia lokalnej specyfiki miasta na szczególną uwagę zasługują dwa spośród nich: Towarzystwo Przyjaciół Sanoka i Ziemi Sanockiej oraz Fundacja Archiwum Ziemi Sanockiej. Towarzystwo Przyjaciół Sanoka i Ziemi Sanockiej, według zapisów statutowych

26 Sanocka Biblioteka Cyfrowa (SBC) - jej utworzenie ma na celu ułatwienie dostępu do źródeł (rękopisy, druki oraz ikonografia) związanych przede wszystkim z regionem Ziemi Sanockiej i Łemkowszczyzny oraz popularyzowanie dziedzictwa kulturowego region (wg opisu projektu na stronie internetowej biblioteki). Publikacje SBC podzielone są na kolekcje: Dziedzictwo kulturowe (kolekcja zawiera szczególnie cenne źródła ( $w$ tym m.in. kopie materiałów ze zbiorów lwowskich) oraz publikacje wydane do 1945 roku) oraz Regionalia (w kolekcji prezentowane są publikacje dotyczące regionu Ziemi Sanockiej i Łemkowszczyzny wydane po 1945 roku). 
jest stowarzyszeniem społeczno-kulturalnym, które wcześniej działało pod nazwami: od 15 grudnia1904 roku, jako Towarzystwo Upiększania Miasta Sanoka, od 25 lipca 1934 roku jako Towarzystwo Przyjaciół Ziemi Sanockiej i od 10 sierpnia 1964 roku jako Towarzystwo Rozwoju i Upiększania Miasta Sanoka. Łączą te Towarzystwa tożsame cele i zadania ujęte w prawomocnych statutach, a także ci sami członkowie, sanoczanie, którzy wielopokoleniowo te Towarzystwa powoływali do życia i organizowali ich działalność. Towarzystwo Przyjaciół Sanoka i Ziemi Sanockiej jest towarzystwem samodzielnym, samorządnym i apolitycznym, kładącym nacisk na patriotyczne wychowanie obywatelskie służące rozwojowi Rzeczpospolitej Polskiej, pielęgnującym dziedzictwo kulturowe oraz polską tożsamość narodową. Towarzystwo może współdziałać przy stwarzaniu warunków dla rozwoju kultury mniejszości narodowych w regionie ${ }^{27}$.

Towarzystwo wystawia swoich kandydatów do Rady Miasta - obecnie jest reprezentowane przez 2 radnych. Jest współwydawcą (wraz z Biblioteką Miejską i Polskim Towarzystwem Historycznym w Sanoku) „Rocznika Sanockiego".

Fundacja Archiwum Ziemi Sanockiej powstała w 2003 roku. Cel organizacji to ochrona dóbr kultury i dziedzictwa narodowego poprzez gromadzenie materiałów dokumentujących życie mieszkańców Sanoka. Do głównych obszarów działania fundacji należą: utrzymywanie archiwum, pomnażanie jego zbiorów i udostępnianie w celach naukowych, prowadzenie prac badawczych, wydawanie „Zeszytów Archiwum Ziemi Sanockiej”28.

Lokalny rynek mediów w Sanoku tworzą trzy czasopisma: „Tygodnik Sanocki”, „Rocznik Sanocki”, „Zeszyty Archiwum Ziemi Sanockiej” oraz portale internetowe: www.esanok.pl, www.isanok.pl, www.sanoczanin.pl, www.bieszczady24.pl. Informacje dotyczące Sanoka można także odnaleźć w mediach regionalnych: elektronicznych: TVP Rzeszów, PR Rzeszów, Radio „Via” oraz w gazetach „Nowiny”, „Super Nowości”, „Kurier Podkarpacki”, „Nowe Podkarpacie”.

Najważniejsze imprezy kulturalne organizowane w mieście, to: Festiwal im. Adama Didura; Międzynarodowe Spotkania Akordeonowe oraz organizowany przez Muzeum Budownictwa Ludowego Jarmark Folklorystyczny. Festiwal im. Adama Didura jest to spotkanie wykonawców muzyki poważnej i operowej, odbywające się corocznie od grudnia 1989, zwyczajowo w trzecim tygodniu września. Impreza jest organizowana przez Sanocki

\footnotetext{
27 Statut Towarzystwa Przyjaciół Sanoka i Ziemi Sanockiej.

28 Współzałożyciel Fundacji, znany w Sanoku działacz polityczny i społeczny, jest autorem publikacji „Sanok. Instytucje kultury”, stanowiącej szeroką panoramę dziejów i współczesności tych placówek, www.encyklopedia-solidarnosci.pl, [27.11.2014].
} 
Dom Kultury. Patronem i donatorem festiwalu są Starostwo i Rada Powiatu Sanockiego. Nazwa festiwalu pochodzi i związana jest z nazwiskiem solisty Adama Didura uznawanego za jednego z najznakomitszych basów przełomu XIX i XX wieku. W ramach festiwalu odbywa się Konkurs Kompozytorski im. Adama Didura oraz liczne warsztaty: literackie, fotograficzne, tańców, śpiewu oraz spotkania autorskie i kino artystyczne. Międzynarodowe Spotkania Akordeonowe są organizowane w cyklu dwuletnim. Gromadzą solistów i zespołów z Polski, Białorusi, Litwy, Rosji, Słowacji i Ukrainy, konkurujących w ośmiu kategoriach solistycznych i kameralnych. Głównym organizatorem jest Państwowa Szkoła Muzyczna im. Wandy Kossakowej, przesłuchania i koncerty odbywają się w Szkole. Państwowa Wyższa Szkoła Zawodowa im. Jana Grodka w Sanoku od 2014 organizuje Festiwal Muzyka na pograniczu Celem Festiwalu jest: prezentacja i promocja twórczości muzycznej i literackiej młodzieży krajów europejskich. Skierowany jest do solistów, zespołów wokalnych oraz zespołów wokalno-instrumentalnych, reprezentujących różne kraje. Uczestnikami Konkursu mogą być uczniowie szkół gimnazjalnych i średnich oraz studenci.

\section{Jarmark Sanocki}

W 2004 roku samorząd miejski Sanoka zorganizował po raz pierwszy Jarmark Ikon. Od 2012 roku święto odbywa się pod zmienioną nazwą Jarmarku Sanockiego. Powodem zmiany nazwy były zapewne kontrowersje związane z pierwotną nazwą jarmarku (ta nazwa odwołuje się do dwóch przeciwnych sobie tradycji: biesiadno-jarmarcznej oraz tradycji sakralnej). Organizatorem Jarmarku Sanockiego jest samorząd miasta Sanok ${ }^{29}$. Całością prac organizacyjnych zajmuje się grupa kilku pracowników Urzędu Miejskiego, która podejmuje decyzje dotyczące formuły i oferty święta. W Urzędzie Miasta zapadła także decyzja o włączeniu wydarzenia do cyklu lokalnych imprez pod wspólnym dla Sanoka, Krosna i Jasła hasłem („Zachowaj Klimat Lata”). Formuła Jarmarku Sanockiego obejmuje ofertę wystawienniczo-handlową, w której wystawcy - artyści i rękodzielnicy oferują do sprzedaży swoje wytwory na straganach oraz rozrywkową - występy artystyczne, atrakcje dla dzieci i ogródki usług gastronomicznych.

Jarmark Sanocki odbywa się w centrum miasta. Scena ulokowana jest w Rynku przy budynku Urzędu Miasta. Stragany wystawców są rozstawione

29 Oficjalnie na Jarmark w 2014 zaproszenie do mieszkańców wystosowały wspólnie samorząd miejski i powiatowy, jednak wyniki badań terenowych zawierają sygnały o wzajemnym dystansie i faktycznych trudnościach we współdziałaniu tych organów, uniemożliwiających organizację wspólnych przedsięwzięć. 
w Rynku oraz na dwóch głównych, przylegających do Rynku ulicach. Do przestrzeni Jarmarku należą też dwa pobliskie place i ogródek jordanowski, na których umiejscowione są zazwyczaj dodatkowe atrakcje dla dzieci i stanowiska gastronomiczne. W przestrzeni, w której organizowany jest Jarmark widoczne są elementy symboliki miasta: flagi samorządowe, flagi w barwach miasta (czerwono-niebiesko-białych), herb Sanoka, logo miasta „SanOK” (związane ogólnie z hasłem „Sanok - miasto kultury”).

Główną ideą święta była od początku przede wszystkim promocja wystawców. Wśród nich na Jarmarku reprezentowani są: wystawcy biżuterii i ozdób, ceramiki, tkanin oraz serwetek, makatek i koronek, przedmiotów z drewna i wikliny, wytwórcy artykułów spożywczych kuchni lokalnej i regionalnej (w ofercie znajdują się m.in. proziaki, swojski chleb bieszczadzki i sery regionalne oraz miody i nalewki). Kilka stanowisk zajmują wystawcy ikon. Obecne jest także stoisko, na którym można znaleźć m.in. ubiory, kilimy, instrumenty gliniane i drewniane. Rzeźbiarze i malarze prezentują witraże i obrazy malowane na szkle. Na stoisku z książkami znajdują się pozycje dotyczące miasta i regionu, a także tematyki ukraińskiej. Wśród oferowanych towarów są też artykuły plastikowe, kadzidełka, zabawki, wata cukrowa i inne. Wystawcy na Jarmarku to przede wszystkim artyści i rękodzielnicy $z$ regionu, choć są wśród nich także twórcy z Ukrainy oraz z innych części Polski; w większości wystawcy indywidualni, rzadziej stowarzyszenia, (np. Koła Gospodyń Wiejskich czy „Stowarzyszenie Ludzi Twórczych" z Brzozowa). Niewielki udział w organizacji Jarmarku mają sponsorzy - lokalni przedsiębiorcy. Tradycyjnie zaangażowana jest właściwie tylko firma przewozowa „Avanti”, która sponsoruje orkiestrę młodzieżową. Część rozrywkowa Jarmarku obejmuje występy artystów lokalnych, regionalnych, (w tym ukraińskich), a także gwiazd muzyki popularnej.

Liczba odwiedzających Jarmark jest trudna do oszacowania. W trakcie badań organizatorzy oceniali poziom frekwencji jako wysoki i zadowalający. W 2014 roku badacze szacowali tę liczbę na ok. 4-5 tysięcy osób.

Program Jarmarku Sanockiego w 2014 roku obejmował:

10.00 - rozpoczęcie Jarmarku

13.00 - $\quad$ występ Sanockiej Młodzieżowej Orkiestry „Avanti” i pokaz musztry paradnej

14.30 - $\quad$ występ zespołu „PodobaMISię”

16.00 - $\quad$ występ zespołu „Czerehat”

17.30 - $\quad$ występ zespołu „Ivo Stars Band”

19.15 - występ zespołu „Kuatech Dyba Sabat Trio”. 


\section{Uwagi końcowe}

Zaprezentowana społeczno-kulturowa charakterystyka badanych miejscowości może stanowić podstawę do analizy procesów tworzenia oraz treści marek lokalnych badanych miast. Dostarcza danych do wnioskowania na temat uwarunkowań zaangażowania ich uczestników, sposobów działania głównych podmiotów, elementów wykorzystywanych w konstrukcji marki czy wreszcie efektywności.

Punktem wyjścia do stworzenia charakterystyki miejscowości było założenie o podobieństwie położenia i kulturowego zróżnicowania obu miast. Wyniki analizy pozwoliły na uchwycenie także istotnych, kształtujących się w historycznym procesie cech specyficznych zróżnicowania kulturowego Przemyśla i Sanoka. Odmienności te wydają się wpływać na różne strategie, jakie w procesach tworzenia marki pojawiają się w działaniach aktorów każdej ze społeczności, a także na treści, jakie uznają za stosowne włączyć do lokalnej marki.

\section{Bibliografia}

Analiza sytuacji na przemyskim rynku pracy 2014-2015, http://www.pup.przemysl.pl/FCK/ file/pliki\%20do\%20pobrania/Analiza_sytuacji_na_przemyskim_rynku_pracy_lata _2014_2015.pdf, [20.03.2015].

Babiński G. (2004), Metodologia a rzeczywistość społeczna. Dylematy badań etnicznych, Kraków.

Bank Danych Lokalnych, http://www.stat.gov.pl/bdl/app/strona.html?p_name=indeks, [20.05.2014].

Błażejewski T., Ciarko PBS Bank STS Sanok wycofało się z ligi. To koniec hokeja w Sanoku?, www.rzeszow.sport.pl, [16.03.2017].

Borowik I., Dyszewska A., Litak E. (2008), Europa - Przemyśl - jednostka: niektóre aspekty transformacji sceny religijnej, „Rocznik Przemyski: Socjologia”, z. 5.

Brygidyn A. (1995), Życie polityczne, [w:] F. Kiryk (red.), Sanok. Dzieje miasta, Kraków.

Chrobaczyński J. (1995), System okupacji, [w:] F. Kiryk (red.), Sanok. Dzieje miasta, Kraków.

Dalecki M. (2002), Przemiany demograficzne w Polsce południowo-wschodniej w latach 1939-1944, „Przemyskie Zapiski Historyczne” 2000-2002, R. XII-XIII.

Diagnoza sytuacji społeczno-gospodarczej Miasta (jakościowa). Zrównoważona Strategia Rozwoju Miasta Sanoka na lata 2013-2024, Sanok 2013.

Florida R. (2010), Narodziny klasy kreatywnej, Warszawa.

Kiryk F. (1995), Lokacja miasta, [w:] F. Kiryk (red.), Sanok. Dzieje miasta, Kraków. 
Kiryk F. (1995), Terytorium i zabudowa, [w:] F. Kiryk (red.), Sanok. Dzieje miasta, Kraków.

Kiryk F., Leśniak F. (1995), Mieszkańcy, [w:] F. Kiryk (red.), Sanok. Dzieje miasta, Kraków.

Leśniak F. (1995), Stosunki ustrojowe, [w:] F. Kiryk (red.), Sanok. Dzieje miasta, Kraków.

Oberc F. (1999), Sanok. Instytucje kultury, Sanok.

Opas T. (1995), Sanok w okresie przedautonomicznym, [w:] F. Kiryk (red.), Sanok. Dzieje miasta, Kraków.

Państwowa Komisja Wyborcza: Wybory i Referenda, http://pkw.gov.pl/352_Wybory_i_referenda, [20.04.2017]

Ranking polskich marek, Edycja X, (2013) dodatek do „Rzeczpospolita”, 17 grudnia.

Ranking najcenniejszych polskich marek, Edycja XIII, (2017) dodatek do „Rzeczpospolita”, 26 stycznia.

Raport o stanie Miasta Przemyśla, 2015, http://bip.przemysl.pl/download/ attachment/50877/raport-o-stanie-miasta-przemysla.pdf; [20.04.2017].

F. Kiryk (red.) (1995), Sanok. Dzieje miasta, Kraków.

Sobala-Gwosdz A. (2008), Przemyśl jako miasto-wrota, „Rocznik Przemyski: Socjologia”, z. 5 .

Sołtys W. (1995), Oświata i szkolnictwo, [w:] F. Kiryk (red.), Sanok. Dzieje miasta, Kraków.

Sołtys W. (1995), Życie gospodarcze, społeczne i polityczne, [w:] F. Kiryk (red.), Sanok. Dzieje miasta, Kraków.

Stachowicz W. (1995), Życie gospodarcze, [w:] F. Kiryk (red.), Sanok. Dzieje miasta, Kraków.

Statut Towarzystwa Przyjaciół Sanoka i Ziemi Sanockiej.

Statystyczne Vademecum Samorządowca 2016, Urząd Statystyczny w Rzeszowie, www. rzeszow.stat.gov.pl/vademecum, [16.03.2017].

Strategia sukcesu miasta Przemyśla na lata 2014-2024. Diagnoza jakościowa. Diagnoza sytuacji społeczno-gospodarczej miasta, Przemyśl 2014, http://bip.przemysl.pl/download/ attachment/6529/zal.pdf, [20.03.2015].

Strategia rozwoju turystyki dla miasta Przemyśla na lata 2008-2015, Przemyśl 2007.

Wojnar K. (2016), Polska klasa kreatywna, Warszawa.

Zając E. (1995), Oświata i szkolnictwo. Życie kulturalne, [w:] F. Kiryk (red.), Sanok. Dzieje miasta, Kraków.

Serwis UM Sanoka, www.sanok.pl, [16.03.2017].

www.autosan.eu, [14.03.2017].

www.sanockabibliotekacyfrowa, [14.03.2017].

www.encyklopedia-solidarnosci.pl, [27.11.2014]. 


\section{SUMMARY}

\section{Przemyśl and Sanok - socio-cultural characteristic of the local communities}

The process of creating a local, regional or national brand is connected with the social and cultural specificity of a region. Considering the above the text gives a short outline of the history and general characteristic of two towns located in the south - eastern part of Poland Voivodes, near the border with Slovakia and Ukraine: Przemyśl and Sanok. In the analysis, particular attention is focused on general socioeconomic characteristics. Among the discussed problems are also: cultural diversity of the city, local political scene, activities of local cultural institutions and NGO's, problems of education and local media market. Town fests and selected cultural events are also presented.

KEYWORDS: town fest, cultural diversity, local cultural institutions, local politics 